\title{
A comprehensive survey of the laminins and collagens type IV expressed in mouse Leydig cells and their regulation by LH/hCG
}

\author{
Séverine Mazaud Guittot, Adélie Vérot, Fanny Odet ${ }^{1}$, Marie-Agnès Chauvin² \\ and Brigitte le Magueresse-Battistoni \\ Inserm U418, UCBL1, UMR INRA 1245, Hopital Debrousse, 29 rue soeur Bouvier, 69322 Lyon Cedex 05, France, \\ ${ }^{1}$ NIH NIEHS 111 TW Alexander Drive Research Triangle Park, Research Triangle Park, North Carolina 27709, USA \\ and ${ }^{2}$ INSERM U870 INRA U1235, Faculté de Médecine Lyon Sud, 165 Chemin du Grand Revoyet, 69600 Oullins, \\ France
}

Correspondence should be addressed to S Mazaud Guittot; Email: severinemazaud@yahoo.fr; lemagueresse@lyon.inserm.fr

A Vérot and F Odet contributed equally to this work

S Mazaud Guittot and B le Magueresse-Battistoni are now at INSERM U870 INRA U1235, Faculté de Médecine Lyon Sud, 165 Chemin du Grand Revoyet, 69600 Oullins, France

\begin{abstract}
Extracellular matrix (ECM) proteins have been shown to alter Leydig cell steroidogenesis in vitro, substantiating the hypothesis that Leydig cell steroidogenic activity and matrix environment are interdependent events. However, the nature of the ECM components synthesized by Leydig cells and their regulation by LH/human chorionic gonadotropin (hCG) remain unknown. Here, we examine the occurrence of the 11 laminin subunits and the $6 \propto$ chains of collagen IV (COL4A1-6) by RT-PCR in Leydig cells cultured with or without LH/hCG. Leydig cells were a tumor Leydig cell line (mLTC-1) or 8-week-old mice Leydig cells. Based on PCR data, it is suggested that normal Leydig cells may synthesize a maximum of 11 laminin heterotrimers and the $6 \alpha$ chains of collagen IV. They also may synthesize various proteases and inhibitors of the metzincin family. The mLTC-1 cells have a limited repertoire as compared with normal Leydig cells. Interestingly, none of the ten proteases and inhibitors monitored is under LH-hCG regulation whereas every protease and inhibitor of the serine protease family yet identified in Leydig cells is under gonadotropin regulation. In addition, a few laminin and collagen subunit genes are regulated by LH/hCG. These are laminins $\alpha 3$ and $\gamma 3$ (Lama3 and Lamc3), Col4a3, and Col4a6, which are negatively regulated by LH/hCG in both Leydig cell types, and Col4a4, which was downregulated in primary cultures but not in mLTC-1 cells. Collectively, the present study suggests that Leydig cells modulate in a selective fashion their matrix environment in response to their trophic hormone. This may alter the steroidogenic outcome of Leydig cells.
\end{abstract}

Reproduction (2008) 135 479-488

\section{Introduction}

Collagen type IV, laminins, nidogens, and heparan sulfate proteoglycans are essential components of basement membranes (BMs). BMs are specialized structures of the extracellular matrix (ECM) with multiple functions, including proliferation, migration, survival, and differentiation (Timpl 1996, Timpl \& Brown 1996). Collagen IV is essential for BM stability. It is composed of three $\alpha$ chains assembled in a triple helix. They are six different chains of collagen type IV, $\alpha 1-\alpha 6$, each encoded by a separate gene, but only three specific protomers, $\alpha 1 \alpha 1 \alpha 2, \alpha 3 \alpha 4 \alpha 5$, and $\alpha 5 \alpha 5 \alpha 6$ (Timpl 1996). While $\alpha 1$ (IV) and $\alpha 2$ (IV) chains are ubiquitously present in BMs, the $\alpha 3-\alpha 6$ (chains) generally have a more restricted distribution (Hudson et al. 2003, Zheng et al. 2005). Laminins are large heterotrimeric glycoproteins consisting of $a, \beta$, and $\gamma$ chain, encoded by specific genes named Lama, Lamb, and Lamc respectively.
To date, five $\alpha$ chains, three $\beta$ chains, and three $\gamma$ chains have been identified, from which 16 laminin heterotrimers have been characterized in vivo (Aumailley et al. 2005). Laminin can bind to collagen IV, entactin/nidogen, heparin sulfate proteoglycan and itself, and is thought to have an organizing role in matrix assembly and the resulting supramolecular architecture (Colognato \& Yurchenko 2000). Thus, the composition of BMs can be highly variable depending on the types of laminin and collagen type IV, and it is now recognized that the unique composition of each BM contributes to its specific functional properties. In addition, its composition may change during development and growth, or in response to injury or an environmental or hormonal stimulus (Enders etal. 1995, Kahsai et al. 1997, Pöschl et al. 2004). Changes in BM composition result from modifications in the balance between ECM component synthesis and degradation, and two major groups of enzymes are 
involved in ECM component degradation, that is, the enzymes of the plasminogen activator (PA) system and the family of matrix metalloproteinases (MMPs; Dano et al. 2005, Page-McCaw et al. 2007).

The testis is divided into two compartments with the seminiferous tubules that produce sperm cells and the interstitial compartment that contains the steroidogenic Leydig cells. In the testis, the biological functions and composition of the BM surrounding the seminiferous tubules have been the subject of many investigations, and its importance is highlighted with the finding that male infertility is associated with abnormal thickening in the BM underlying the seminiferous epithelium (de Kretser et al. 1975). Indeed, the BM is the structural basis of testis cord organization at the time of testis differentiation in the developing gonad (Dym 1994, Clark et al. 2000). In adult life, it is essential for the maintenance of the differentiated functions of Sertoli cells that are to provide structural and nutritional support for the developing germ cells (Griswold 1998, Siu \& Cheng 2004).

Conversely, little is known on the composition and functional importance of the ECM components of Leydig cell origin. It is known that Leydig cells are not surrounded by a continuous BM in the adult testis, but that they exhibit patches of laminin and type IV collagen on the cell surface. A direct association of these ECM proteins with Leydig cells has also been evidenced (Kuopio \& Pelliniemi 1989). In addition, ECM affects Leydig cell proliferation, testosterone production, and gene expression (Vernon et al. 1991, Diaz et al. 2002, 2005). However, the nature of the ECM components synthesized by Leydig cells and their regulation by the trophic hormone luteinizing hormone (LH) have remained unexplored.

In the present study, we show at the RNA level that Leydig cells synthesize various laminins and collagens type IV subunits and a few are downregulated by LH/human chorionic gonadotropin (hCG) via cAMP. Leydig cells also synthesize various proteinases and inhibitors, but none of the molecules here studied are under LH/hCG regulation. Taken collectively with our previous study reporting a rapid and transient induction of PA of the urokinase-type in cultured Leydig cells upon LH stimulation (Odet et al. 2006), these data indicate that Leydig cells can selectively modulate their matrix environment in response to $\mathrm{LH} / \mathrm{hCG}$.

\section{Results}

\section{RT-PCR screening of laminins and collagens type IV}

The list and sequences of the designed specific primers for PCR studies are described in Table 1. Lamb3 is not presented because it is not expressed in the mouse testis (Häger et al. 2005). Total RNA was recovered from adult mice testes, 3-week-old Sertoli cells that had been cultured for 2 days in basal conditions, 8-week-old freshly isolated Leydig and mLTC-1 cells. A PCR product of the right size and sequence (not shown) was detected for each of the molecules studied using total RNA from adult testes or Sertoli cells. PCR using specific primers directed against Sox9 was used to detect Sertoli cell contamination of the 8-week-old Leydig cells.

The expression pattern of the laminin $\alpha$ subunits was different between normal Leydig and mLTC-1 cells. Normal Leydig cells exhibited a PCR product for every laminin $\alpha$ subunit with the exception of the Lama1 subunit, whereas mLTC-1 cells only expressed the Lama1, Lama3 (weakly), and Lama4 (Fig. 1). The two Leydig populations exhibited a PCR product for Lamb1, Lamb2, Lamc1, and Lamc3. Lamc2 was absent in mLTC-1 cells and weakly present in normal Leydig cells (Fig. 1). Since there was a weak Sox9 PCR band in normal Leydig cells and no band for Lamc2 in the mLTC-1 cells (Fig. 1), it is likely that the weak band of Lamc2 detected in the 8-week-old Leydig cells resulted from the weak contamination of the Leydig cell preparations with Sertoli cells expressing Sox9. Other PCR signals for laminin subunits had roughly similar intensities in Sertoli and Leydig cell preparations (Fig. 1). Thus, normal Leydig and mLTC- 1 cells may be able to synthesize a maximum of 11 and 7 laminin heterotrimers respectively (Table 2 ).

Regarding the six $\alpha$ chains of collagen IV, the two populations exhibited a PCR product for Col4a2-6. The signal for Col4a2-5 was weaker in $\mathrm{mLTC}-1$ cells than in normal Leydig cells. The signal for Col4a6 was weak in both Leydig cell types. Normal Leydig cells also exhibited a PCR product for Col4a1 (Fig. 1). Based on PCR data, it sounds unlikely that PCR signals in normal Leydig cells result from the weak contamination of the Leydig fraction with Sertoli cells. These data indicate that normal Leydig cells are probably able to synthesize the three specific protomers $\alpha 1 \alpha 1 \alpha 2, \alpha 3 \alpha 4 \alpha 5$, and $\alpha 5 \alpha 5 \alpha 6$, whereas mLTC- 1 cells can only synthesize the trimers $\alpha 3 \alpha 4 \alpha 5$ or $\alpha 5 \alpha 5 \alpha 6$ (Table 2).

\section{Addition of hCG alters the expression of ECM proteins in Leydig cells}

In these experiments, the expression of StAR was monitored to ensure that Leydig cells responded significantly $(P<0.05)$ to hCG and $b_{2}$ CAMP (shown in the mLTC-1 cells) in our experimental conditions (Fig. 2). For the semi-quantitative RT-PCR experiments, we ran 29 cycles for Lama3 and Lamc3 (Fig. 2), and 25 cycles for the Col4a3, Col4a4, and Col4a6 (Fig. 3). The signals detected by RT-PCR using total RNA from mLTC-1 cells were weaker than the signals generated with total RNA from 8-week-old Leydig cells, indicating a relative low abundance of the transcripts in the tumoral cells (Figs 2 and 3 ).

Most of the laminins (Lama1, Lama2, Lama4, Lama5, Lamb1, Lamb2, Lamc1, and Lamc2) and collagen (Col4a1, $\mathrm{Col} 4 \mathrm{a} 2$, and $\mathrm{Col} 4 \mathrm{a} 5$ ) subunit genes were not regulated by LH/hCG (not shown). Conversely, laminins $\alpha 3$ and $\gamma 3$ (Fig. 2), and Col4a3, Cola4a4, and Col4a6 (Fig. 3) were 
Table 1 List and sequence of the designed specific primers for PCR studies.

\begin{tabular}{|c|c|c|c|c|c|}
\hline & \multirow[b]{2}{*}{ Accession no. } & \multicolumn{2}{|c|}{ Primers $\left(5^{\prime}-3^{\prime}\right)$} & \multirow[b]{2}{*}{ Size (bp) } & \multirow[b]{2}{*}{$T_{\text {Opt }}(\mathrm{C})$} \\
\hline & & Forward & Reverse & & \\
\hline Hprt1 & NM_013556 & ССТGСТGGATTACATTAAAGСАСТG & GTCAAGGGCATATCCAACAACAAAC & 354 & 65 \\
\hline$R p / 19^{\mathrm{a}}$ & NM_009078 & CTG AAG GTC AAA GGG AAT GTG & GGA CAG AGT CTT GAT GAT CTC & 195 & 60 \\
\hline StAR & NM_011485 & GCATACTCAACAACCAGGAAGG & CTGGTTGATGATTGTCTTCGGC & 511 & 65 \\
\hline$S t A R^{\mathrm{a}}$ & & TTGGGCATACTCAACAACCA & CCTTGACATTTGGGTTCCAC & 198 & 60 \\
\hline Sox 9 & AF421878 & TCC AGC AAG AAC AAG CCA CAC G & CTT GTC CGT TCT TCA CCG & 270 & 58 \\
\hline \multicolumn{6}{|c|}{ 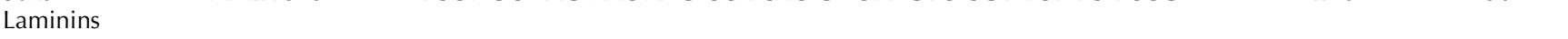 } \\
\hline Lama1 & NM_008480 & TTACGTGGGTGGATTGCCTCAT & TGTTCCTGTCCATCACTGTAGG & 449 & 61 \\
\hline Lama2 & NM_008481 & GTATGGTCTTGAAAATACAACT & GATTCTGCTCTGGAGTTGGTCC & 206 & 60 \\
\hline Lama3 & XM_140451 & TTGAAGGCACAGGCTATGCTCG & TGTATCGTTCAACCTGACAACC & 454 & 65 \\
\hline $\operatorname{Lama}^{\mathrm{a}}$ & & AAATGCTCССТTCССАAАCT & ATCTCTCCCGTTGTTGATGG & 193 & 60 \\
\hline Lama4 & NM_010681 & TGCTCAAACCAGGAGTGTC & CACCTTTCCGTGTTTCCCTA & 378 & 65 \\
\hline Lama5 & NM_001081171 & CACCGAAGTGGTCTATTCTGGC & CСТACGСТTACATTGACACTCC & 446 & 65 \\
\hline Lamb1 & NM_008482 & $\begin{array}{l}\text { GTACATTGGCTCCAGATGTGAT- } \\
\text { GACT }\end{array}$ & GGCAATGGTCCССTTCTGTGTGGT & 184 & 65 \\
\hline Lamb2 & NM_008483 & AGAAGGCAGAGACAGTCCAAGC & GTATTGGTCACCTACTTGTTCC & 328 & 60 \\
\hline Lamc1 & NM_010683 & GTGTGAACGATAACAAGACAGC & CATACCGTTCACСТCATTATCC & 268 & 62 \\
\hline Lamc2 & NM_008485 & TCGTATCAGCACAGTCTCCG & GCAACCTTCTGGCTAATAGAGG & 421 & 62 \\
\hline Lamc3 & NM_011836 & TTGCAGGGCAGACACTCGTT & GTCCTCCAGTCTTACTACTACG & 226 & 61 \\
\hline \multicolumn{6}{|l|}{ Collagens } \\
\hline Col4a1 & NM_009931 & TATCTCTGGGGACAACATCCG & САTCTCGСTTCTCTCTATGGTG & 321 & 65 \\
\hline Col4a2 & NM_009932 & GCСАCТАСТTCGСТАACAAG & GACAGACGGTTGGAATGAGTGC & 469 & 65 \\
\hline Col4a3 & NM_007734 & ATTAGTGGCAGAGCTCTCGAAC & CATTCTTTCTGGGTTCAGCGAAG & 320 & 65 \\
\hline Col4a4 & NM_007735 & TGCGGCTССТСТTССТАTGAT & GCTGGGCCTGAACTTCTTTC & 397 & 65 \\
\hline Col4a $4^{a}$ & & СТССТGGTTСТССАСАGTCAG & AAGGGCAGAGTGCTAAACACA & 167 & 64 \\
\hline Col4a5 & NM_007736 & TAGCCGATGTCAAGTATGC & TTGCTCTGGCACATTGCTGAGG & 250 & 61 \\
\hline Col4a6 & NM_053185 & TCGTGTCTTGAGGACTTCCG & TGTTAGCACCAGATGGATGG & 419 & 61 \\
\hline Col4a6 ${ }^{\mathrm{a}}$ & & AGAAAGCCCATAACCAGGATCT & GCTGATATACTGGGGAATCTGG & 194 & 60 \\
\hline \multicolumn{6}{|c|}{ (6) } \\
\hline Adam 21 & NM_020330 & САССТАCACAGAGGAACACACC & АСТTСТTAGССТСТTСААСТСС & 310 & 61 \\
\hline Cathepsin L CtsI & NM_009984 & ATGAGGAAGAGTGGAGGAGAGC & GTCATTAGCCACAGCGAACTCG & 541 & 68 \\
\hline Mmp2 & NM_008610 & СТATTCTGTCAGCACTTTGG & CAGACTTTGGTTCTCCAACTT & 309 & 58 \\
\hline Мmp3 & NM_010809 & АСТСТАССАСТСАGCCAAGG & TCCAGAGAGTTAGACTTGGTGG & 348 & 61 \\
\hline Мmp9 & NM_013599 & TGTTCAGCAAGGGGCGTGTC & AAACAGTCCAACAAGAAAGG & 461 & 63 \\
\hline Mmp14 & NM_008608 & CTGATGACGATCGCCGTGGCATCC & GCGTCTGAAGAAGAAGACAGCGAGG & 880 & 65 \\
\hline \multicolumn{6}{|l|}{ Inhibitors } \\
\hline Timp1 & NM_011593 & CTGGCATCCTCTTGTTGCTA & AGGGATCTCCAGGTGCACAA & 585 & 56 \\
\hline Timp2 & NM_011594 & ATCAGAGCCAAAGCAGGTGAGCG & GGTAATGTGCATCTTGCСАTCTCC & 243 & 69 \\
\hline Timp3 & NM_011595 & CCA GAC AAG AGC ATC AGC & АСТTСТGССААСТТССТТАТСС & 481 & 63 \\
\hline Timp4 & NM_080639 & TTT GAC CAT CAC CAC CTG CTG T & ACT TCA GCC AAA CAG CСС АCT C & 375 & 69 \\
\hline
\end{tabular}

The optimal temperature $\left(T_{\mathrm{Opt}}\right)$ for annealing, the size of the expected PCR fragments, and the source for the design of the primers are reported. The number of cycles was determined for each set of primers. It ranged from 21 to 30.

${ }^{\text {a }}$ Primers designed specifically for real time quantitative PCR.

significantly $(P<0.05)$ downregulated by $\mathrm{LH} / \mathrm{hCG}$ in primary cultures, with a fold decrease ranging from -30 to $-60 \%$ depending on the molecule, and when compared with time-matched controls. Effects were time dependent. In the case of Lama3, Col4a3, and Col4a4, first significant effects $(P<0.05)$ were detected after $2 \mathrm{~h}$ and maintained at 6 and $24 \mathrm{~h}$ of stimulation. Lamc3 and Col4a6 were also significantly $(P<0.05)$ downregulated by hCG after $24 \mathrm{~h}$ of stimulation but no significant effect was detected at earlier times (Figs 2 and 3).

The effects observed in $\mathrm{mLTC}-1$ cells were very similar to those described in normal Leydig cells with the exception of Col4a4, which was not regulated in mLTC1 cells (Fig. 3). However, the kinetics of the effects was slightly different depending on the molecule. For example, in mLTC-1 cells, Lama3 was not regulated after $2 \mathrm{~h}$ of hCG stimulation. Lamc3 was significantly downregulated $(P<0.05)$ as soon as $6 \mathrm{~h}$ of stimulation
(Fig. 2). Col4a3 was transiently downregulated after $6 \mathrm{~h}$ of hCG stimulation and Col4a 6 was downregulated after 6 and $24 \mathrm{~h}$ of hCG stimulation (Fig. 3).

The addition of $1 \mathrm{mM} \mathrm{bu} \mathrm{b}_{2} \mathrm{CAMP}$ was found to mostly mimic the effects induced by hCG (shown for the mLTC-1 cells), indicating the involvement of the protein kinase $A$, even though little variation was observed. For example, Lama3 was significantly downregulated by $b_{2} \mathrm{CAMP}$ from $2 \mathrm{~h}$ onwards (Fig. 2). Col4a3 was not significantly downregulated with $\mathrm{bu}_{2} \mathrm{cAMP}$, although a tendency existed at $6 \mathrm{~h}$ consistent with the hCG downregulation of Col4a3 at 6 h of stimulation (Fig. 3). A similar situation was described for Col4a6, and no significant reduction of Col4a6 was observed at $24 \mathrm{~h}$ of stimulation with $\mathrm{bu}_{2}$ cAMP (Fig. 3).

In order to further validate the semi-quantitative data, real-time PCR was carried out using Rp/19 as a housekeeping gene. Data presented in Figs 2D and 3D indicate 


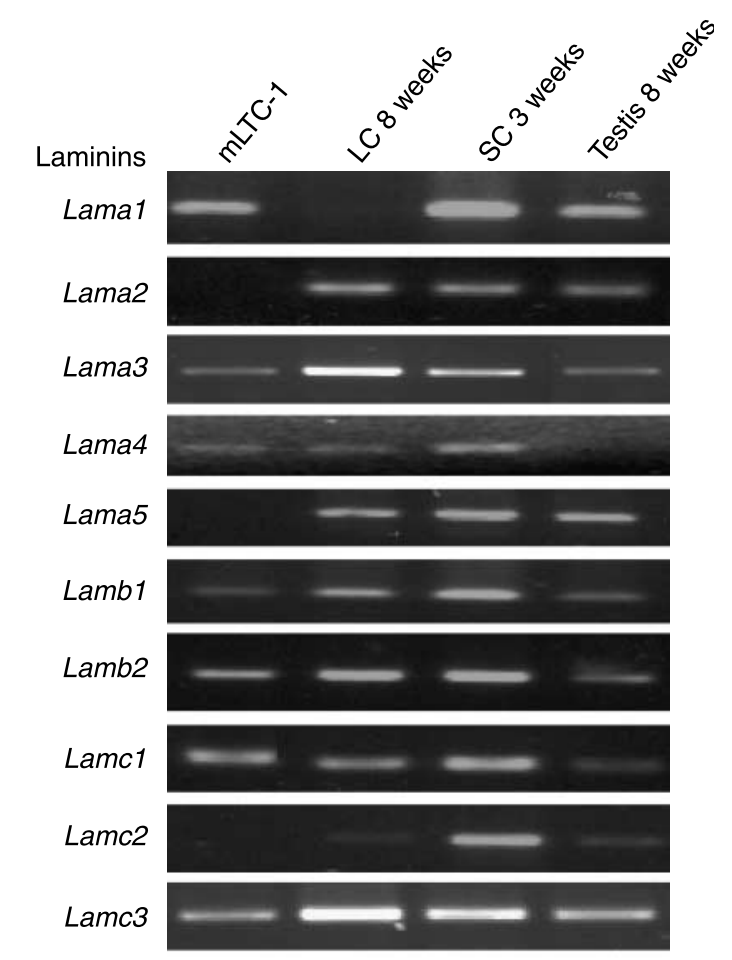

Collagen IV
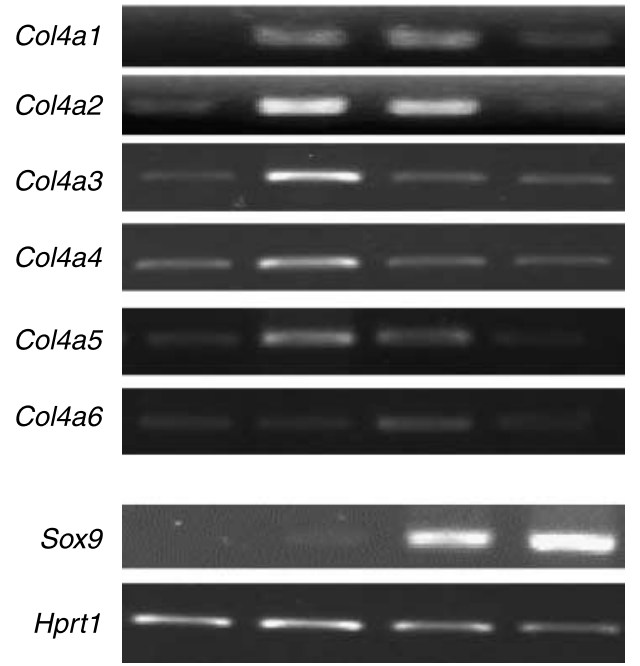

Figure 1 RT-PCR analysis of various laminins and collagen subunit genes in mLTC-1 cells, freshly isolated Leydig cells recovered from 8-week-old testes, Sertoli cells recovered from 3-week-old testes, which had been cultured for 5 days in basal conditions, and 8-week-old mice testes. The set of primers used is listed in Table 1. RT-PCR studies were also conducted using primers directed against $\mathrm{Hprt} 1$ to ensure that equal amounts of material were used, and against Sox 9 to assess the purity of Leydig cells. A DNA ladder was included in each gel for accurate determination of the size of the PCR product and each amplicon was sequenced (not shown).

that StAR was upregulated (a twofold increase; $P<0.05$; $n=3$ ) following a hCG treatment of $24 \mathrm{~h}$ in 8 -week-old Leydig cells. Using the same series of samples, we observed a significant $(P<0.05 ; n=3)$ downregulation of Lama3,
Lamc3, Col4a3 (a 4-fold decrease), Col4a4 (a 2.5-fold decrease), and Col4a6 (a 7-fold decrease) in the 8-weekold Leydig cells treated for $24 \mathrm{~h}$ with hCG $(100 \mathrm{ng} / \mathrm{ml})$. Lower sensitivity of the semi-quantitative PCR versus realtime PCR probably explains differences in the fold changes.

\section{RT-PCR screening of various proteases and inhibitors and $h C G$ regulation}

The list and sequences of the designed specific primers for PCR studies are described in Table 1. Samples studied are as described in Fig. 1. A PCR product of the right size and sequence (not shown) was detected for each of the molecules studied using total RNA from adult testis or Sertoli cells (Fig. 4). Leydig and mLTC-1 cells displayed a PCR product for Mmp3 and Mmp14. No PCR product was found for the gelatinases Mmp2 and Mmp9 in mLTC-1 cells. There was a weak band for Mmp2 but no band for Mmp9 in 8-week-old Leydig cells. The weak Mmp2 band may result from the low contamination of the Leydig cell preparations with Sertoli cells (Fig. 1). Indeed, no gelatinolytic activity has ever been detected using Leydig cell-concentrated culture media (Odet et al. 2006).

A PCR product corresponding to tissue inhibitor of MMPs (Timps) 1-4 was also evidenced in the 8-week-old Leydig cells whereas mLTC-1 cells had a PCR product for Timp1, Timp3, and Timp4 but not for Timp2 (Fig. 4). The two Leydig populations exhibited a PCR product for cathepsin L (Ctsl; Mathur et al. 1997), and a disintegrin and metalloproteinase domain (Adam)21 (originally named Adam31 in Liu \& Smith 2000), as expected. None of the proteases or inhibitors present in Leydig cells were under $\mathrm{LH}-\mathrm{hCG}$ regulation at the time-points investigated (2, 6, and $24 \mathrm{~h}$; not shown).

\section{Discussion}

In the present study, we have investigated the in vitro occurrence of the laminins and collagens type IV subunit genes in adult Leydig cells and a tumoral Leydig cell line, and their regulation by gonadotropins. We have also examined whether various proteases and inhibitors specifically of the matrix metalloproteinase family are expressed in these cells and under a regulation by gonadotropins. The rationale for this study stems from previous observations. First, Leydig cells produce less testosterone upon LH stimulation when cultivated in plates coated with ECM components (Diaz et al. 2002, 2005). Secondly, Leydig cells have contacts with various ECM components (Fawcett et al. 1973), although they do not synthesize a continuous BM (Kuopio \& Pelliniemi 1989). Thirdly, Leydig cells respond to LH in vitro by a transient burst of urokinase, a matrix degrading enzyme, concomitantly with an enhanced StAR expression (Odet et al. 2006). Collectively, these data highly suggest that a link exists between the capacity of Leydig cells to produce testosterone and their matrix environment. 
Table 2 List of extracellular matrix (ECM) molecules potentially synthesized by Leydig cells based on PCR studies.

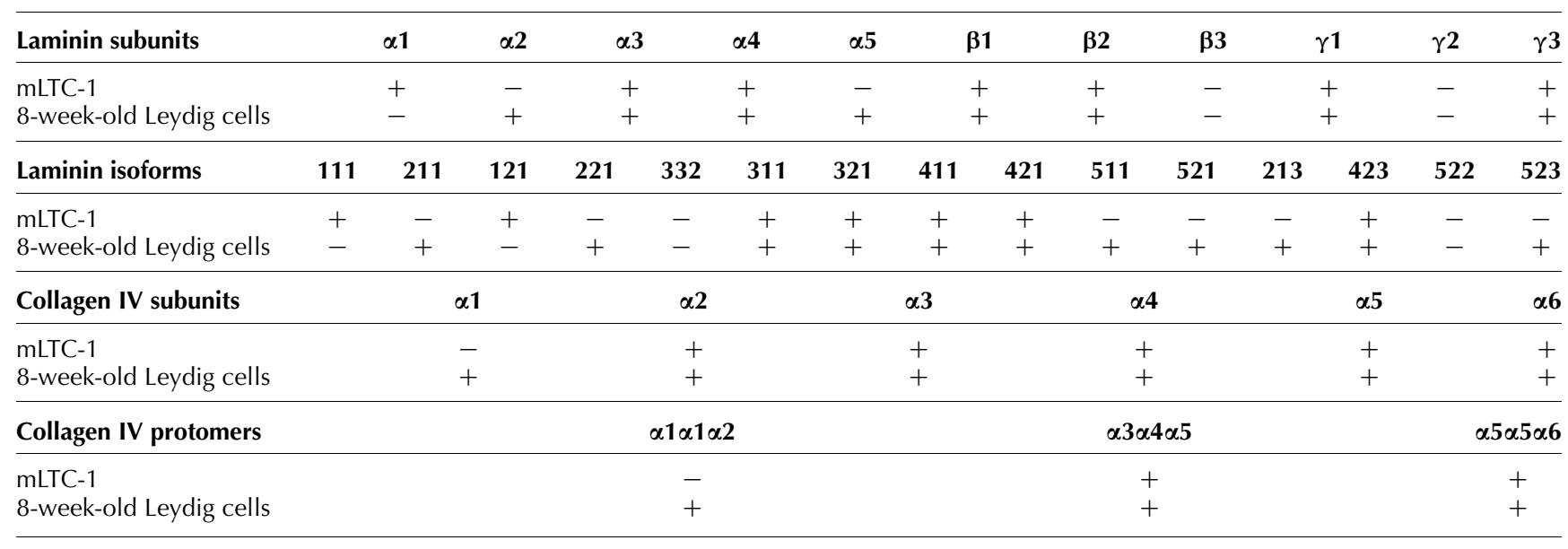

In a first series of experiments using an RT-PCR procedure, we show the presence of mRNAs encoding several laminins and collagens type IV, MMPs, and TIMPs, and we evidence a different repertoire between the tumoral and the normal Leydig cells. Differences observed relate to the identity of the molecules, their relative abundance and gonadotropin regulation. Specifically, tumoral cells express a smaller repertoire than normal cells. In addition, some laminins or collagens IV are present (at least at the RNA level) exclusively in one but not in the other cell type. We also show (although this was not quantified) a weaker level of expression of the ECM components in the mLTC- 1 cells as compared with normal Leydig cells. We also evidence that normal Leydig cells are weakly contaminated with Sertoli cells. Thus, it is possible that differences account for the tumoral phenotype of the $\mathrm{mLTC}-1$ cells.

Normal Leydig cells have a PCR product for Lama2 whereas the mLTC- 1 cells exhibit a PCR product for Lama1. Laminin $\alpha 1$ and $\alpha 2$ chains may play comparable functions since laminin $\alpha 1$ chain corrects male infertility caused by the absence of laminin $\alpha 2$ chain (Häger et al. 2005). Interestingly, Lama3 and Lamc3 are downregulated by hCG, although with a kinetics slightly different depending on the laminin subunit and the cell type. Thus, provided laminin subunits are translated and assembled into proteins, three and five laminins potentially synthesized would be under LH-hCG control in mLTC1 and normal Leydig cells respectively. Lamc3 is unique because it is located in murine BMs (Gersdoff et al. 2005), and mouse Leydig cells express Lamc3 (livanainen et al. 1999; this study). Conversely, it is associated with nonBM structures in the rat (Koch et al. 1999), such as the apical ectoplasmic specializations in adult rat testes (Yan \& Cheng 2006).

Regarding collagens IV, mLTC-1 cells exhibit a PCR product for the $\alpha 2-6$ chains of collagen IV but no signal is evidenced for the $\alpha 1$ chain contrasting with normal Leydig cells. In addition, the regulation of the $\alpha 3, \alpha 4$, and $\alpha 6$ chains of collagen IV by hCG is different between the two cell types, in terms of the kinetics of downregulation of the Col4a3 and Col4a6 by hCG, and also Col4a4 is not regulated by hCG in the $\mathrm{mLTC}-1$ cells. These differences may well be related to the different properties of these cells and the tumoral nature of the mLTC-1 cells. Indeed, the $\alpha 1 \alpha 1 \alpha 2$ protomer is essential for structural integrity of BMs and of BM-like structures (Pöschl et al. 2004). Interestingly, the protomers $\alpha 3 \alpha 4 \alpha 5$ and $\alpha 5 \alpha 5 \alpha 6$, but not the protomer $\alpha 1 \alpha 1 \alpha 2$, are potentially under gonadotropin regulation in the normal Leydig cells.

Few studies have explored the hormonal regulation of ECM components. To date, differential expression of several laminins and $\alpha$ chains of collagens has been shown in mice models with testicular androgen deficiency (Petrusz et al. 2005, Denolet et al. 2006, Wang et al. 2006, Zhang et al. 2006). Other experiments conducted in vitro have shown that thyroid hormones on Sertoli cells (Ulisse et al. 1998) and estrogens on Leydig cells (Yashwanth et al. 2006) can regulate some ECM components. However, an in silico analysis reveals no consensus sequence for CRE in the $5^{\prime}$ untranslated promoter region of the regulated laminins and collagen subunit genes (not shown). Furthermore, it is possible that the pattern of ECM expression and regulation by hormones varies with the differentiation status of Leydig cells during development and in adult life.

In addition to studying the hormonal regulation of the laminin and the collagen subunit genes, we have examined if the Mmps and Timps identified in Leydig cells as well as Adam21 and cathepsin L previously reported to be present in Leydig cells (Mathur et al. 1997, Liu \& Smith 2000) were under LH-hCG regulation. ADAM21 is a cell-surface protein which exhibits metalloproteinase activity (Primakoff \& Myles 2000) and cathepsin $\mathrm{L}$ belongs to the cysteine family of protease and is under FSH regulation in Sertoli cells (Penttila et al. 1995). We observed no regulation of these molecules by hCG. Given that every serine proteases and serine protease inhibitors yet identified in Leydig cells are 

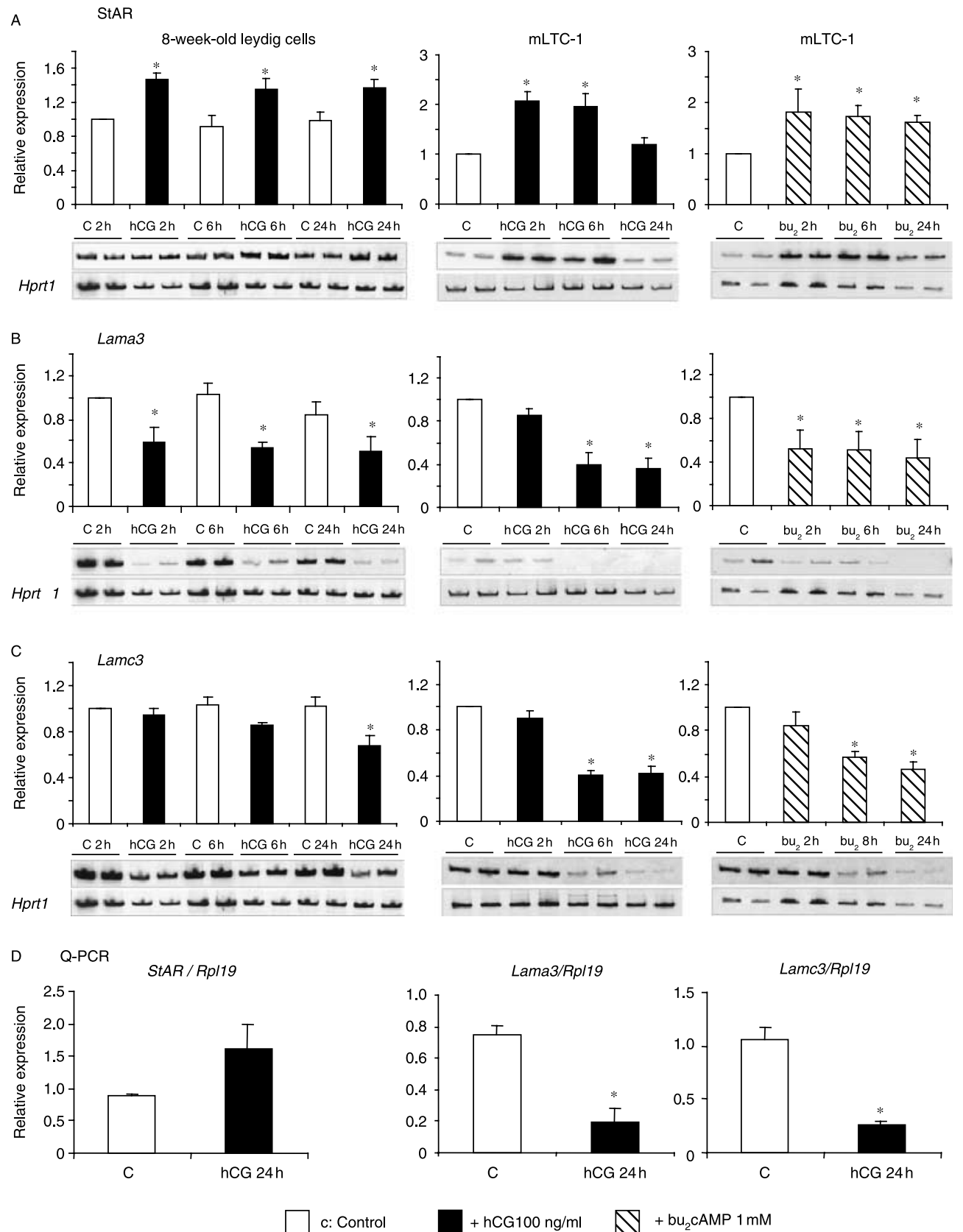

Figure 2 Effect of hCG and bu ${ }_{2}$ CAMP on the expression levels of (A) StAR, (B) Lama3, and (C) Lamc3 on primary cultures of Leydig cells isolated from 8-week-old testes and in mLTC-1 cells, assessed using a semi-quantitative RT-PCR procedure. Leydig and mLTC-1 cells were cultured for 2, 6, or 24 h with or without $100 \mathrm{ng} / \mathrm{ml} \mathrm{hCG}$ or $1 \mathrm{mM} \mathrm{bu}_{2} \mathrm{CAMP}$. Autoradiographs were scanned and expression level was normalized to the Hprt1 signal. The values correspond to the mean \pm s.E.M. of $n=6$ independent experiments of triplicates (Leydig cells) or $n=3-7$ independent experiments of duplicates (mLTC- 1 cells). Asterisks indicate significant differences relative to untreated cells of the time-matched control (Leydig cells) or control $\mathrm{mLTC}-1$ cells $(C)(P<0.05$, Kruskal-Wallis ANOVA followed by Dunn's test). A representative gel of one experiment and the corresponding Hprt1 signal are presented. (D) Effect of a 24-h hCG treatment on the expression levels of StAR, Lama3, and Lamc3 on primary cultures of Leydig cells isolated from 8-week-old testes, assessed using real-time PCR. The Rp/19 levels normalized values correspond to the mean \pm s.E.M. of $n=3$ independent experiments of duplicates, and asterisks indicate significant differences relative to untreated cells of the time-matched control Leydig $(P<0.05, t$-test).

under gonadotropin regulation, and that urokinase is elevated rapidly and transiently following $\mathrm{LH} / \mathrm{hCG}$ stimulation (Odet et al. 2006), our data may suggest that gonadotropins regulate the expression of proteases and inhibitors in a selective manner. Specifically, it is possible that proteases, such as urokinase, exert a primary role in Leydig cells. It is a matrix degrading enzyme with a large spectrum of activities towards most of ECM molecules (Dano et al. 2005). In addition, proteases are generally synthesized as proenzymes and urokinase can process 

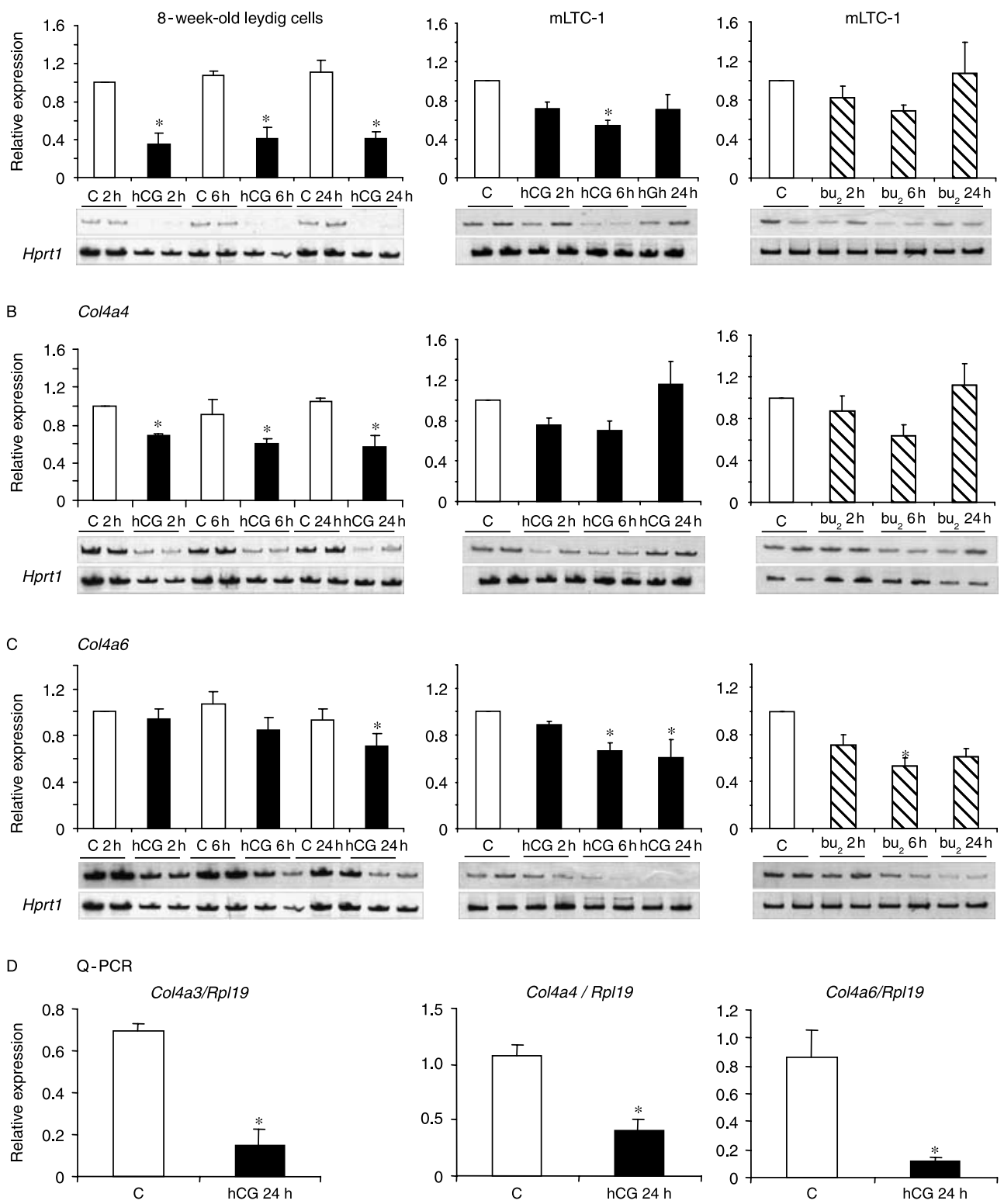

c : Control

$+\mathrm{hCG} 100 \mathrm{ng} / \mathrm{ml}$

$\nabla+b_{2}$ cAMP $1 \mathrm{mM}$

Figure 3 Effect of hCG and bu $\mathrm{b}_{2} \mathrm{AMP}$ on the expression levels of (A) $\mathrm{Co} / 4 \mathrm{a} 3$, (B) $\mathrm{Co} / 4 \mathrm{a} 4$, and (C) Col4a6 on primary cultures of Leydig cells isolated from 8-week-old testes and in mLTC-1 cells, assessed using a semi-quantitative RT-PCR procedure. Leydig and mLTC-1 cells were cultured for 2, 6, or 24 h with or without $100 \mathrm{ng} / \mathrm{ml} \mathrm{hCG}$ or $1 \mathrm{mM} \mathrm{bu}$ CAMP. Autoradiographs were scanned and expression level was normalized to the Hprt1 signal. The values correspond to the mean \pm S.E.M. of $n=3-5$ independent experiments of triplicates (Leydig cells) or $n=4-5$ independent experiments of duplicates (mLTC-1). Asterisks indicate significant differences relative to untreated cells of the time-matched control (Leydig cells) or control mLTC-1 cells (C) $(P<0.05$, Kruskal-Wallis ANOVA followed by Dunn's test). A representative gel of one experiment and the corresponding $H$ prt 1 signal are presented. (D) Effect of a 24-h hCG treatment on the expression levels of Col4a3, Col4a4, and Col4a6 on primary cultures of Leydig cells isolated from 8-week-old testes, assessed using real-time PCR. The Rp/19 levels-normalized values correspond to the mean \pm s.E.M. of $n=3$ independent experiments of duplicates, and asterisks indicate significant differences relative to untreated cells of the time-matched control Leydig $(P<0.05, t$-test).

them to an active form directly or through a cascade of sequential activation (Dano et al. 2005, Page-McCaw et al. 2007). In that scheme, urokinase upon $\mathrm{LH} / \mathrm{hCG}$ stimulation will initiate a cascade of proteolytic events, and the various proteases expressed in Leydig cells will be activated, thus altering local matrix environment, not only through the degradation of ECM molecules synthesized by their own but also through ECM molecules originating from endothelial cells. Indeed, Leydig cells are stabilized within the interstitium through attachments 


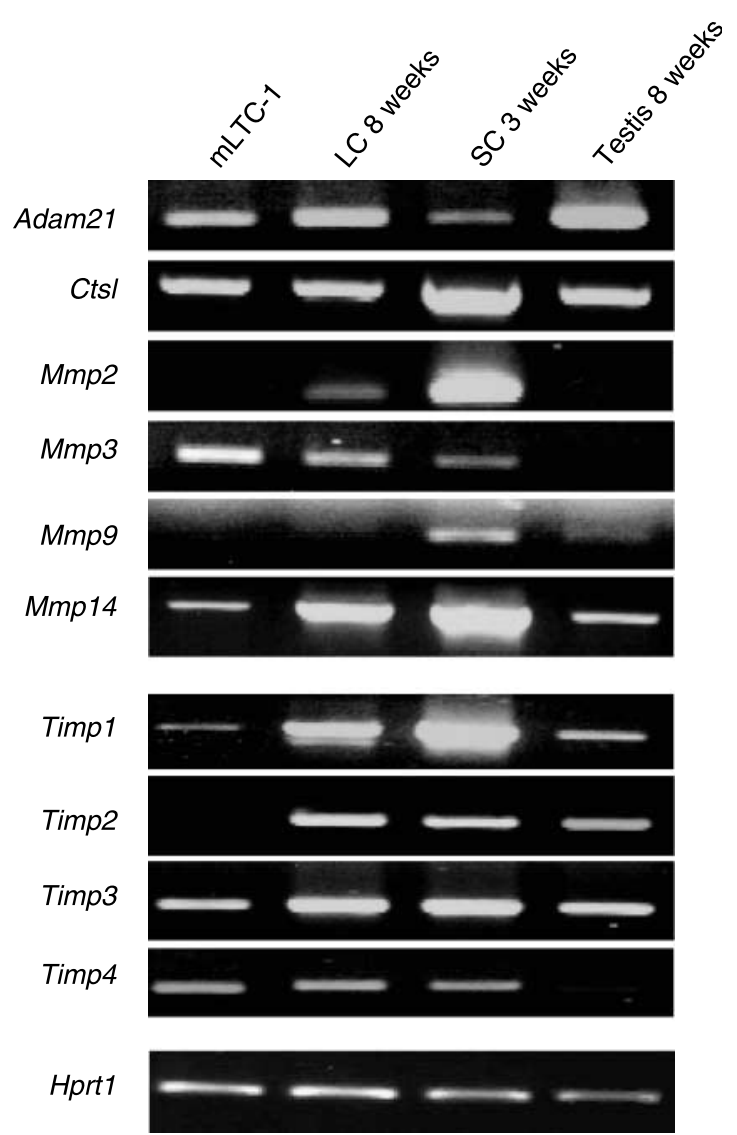

Figure 4 RT-PCR analysis of various proteases and inhibitors in $\mathrm{mLTC}-1$ cells, freshly isolated Leydig cells recovered from 8-week-old testes, Sertoli cells recovered from 3-week-old testes which had been cultured for 5 days in basal conditions, and 8-week-old mice testes. The set of primers used is listed in Table 1. RT-PCR studies were also conducted using primers directed against Hprt1 to ensure that equal amounts of material were used. A DNA ladder was included in each gel for accurate determination of the size of the PCR product and each amplicon was sequenced (not shown).

made to BM components that surround blood vessels and lymphatic endothelium (Fawcett et al. 1973, Kuopio \& Pelliniemi 1989, Vernon et al. 1991).

Collectively, our data raise the hypothesis that the positive regulation exerted by $\mathrm{LH}-\mathrm{hCG}$ on steroidogenesis is the result of two phenomena. A direct and welldescribed effect of LH-hCG on steroidogenesis through binding to its receptor and activation of target genes and enhancement of certain steroidogenic enzymes including StAR (Stocco et al. 2005), and an indirect pathway that is to prevent the inhibiting role exerted by the matrix environment on the steroidogenic capacity of Leydig cells. For example, it has been shown that type IV collagen induces downregulation of steroidogenic response to gonadotropins in adult rat Leydig cells (Diaz et al. 2005). Such inhibition will be exerted at two levels. First, there will be a selective inhibition of ECM synthesis, as shown in the present study. Secondly, there will be an enhancement of the matrix degrading enzyme urokinase (Odet et al. 2006, Le Magueresse-Battistoni 2007), and urokinase will degrade ECM molecules directly or through the activation of the other proteases present locally. Future studies will have to be designed to determine the soundness of such a hypothesis.

\section{Materials and Methods \\ Animals, tissues, and cell preparations}

Swiss male CD-1 mice, aged 3 and 8 weeks, were purchased from Elevage Janvier (Le Genest, France). Animals were killed by $\mathrm{CO}_{2}$ asphyxia before the removal of testes. Testes were immediately used for cell preparations or stored at $-70{ }^{\circ} \mathrm{C}$ for RNA analysis. Experiments were conducted according to the Guide for the Care and Use of Laboratory Animals.

Sertoli cells were isolated from 3-week-old mice testes and cultured in HAM's F12-DMEM (Life Technologies) at $32{ }^{\circ} \mathrm{C}$ in a humidified atmosphere of $5 \% \mathrm{CO}_{2}$ as described previously (Le Magueresse-Battistoni et al. 1998). At the end of the enzymatic procedure, the Sertoli cell suspension was washed with fresh culture medium and cells were seeded in six-well plates at a ratio of $1 \times 10^{6}$ viable cells/well in Ham's F12-DMEM. They were cultured for 2 days. At that time, the purity of the cultures was higher than $90 \%$, and contamination was mainly due to residual germ cells (an average of 5-7\%; not shown).

Leydig cells were isolated from 8-week-old mice testes and cultured in HAM's F12-DMEM at $32{ }^{\circ} \mathrm{C}$ in a humidified atmosphere of $5 \% \mathrm{CO}_{2}$ as described previously (Carreau et al. 1988). Briefly, testes were decapsulated and digested with $0.25 \mathrm{mg} / \mathrm{ml}$ collagenase at $32{ }^{\circ} \mathrm{C}$ for $10 \mathrm{~min}$. The digestion procedure was stopped by dilution with fresh medium, followed by two successive washes and centrifugations. Interstitial cells were purified on a discontinuous Percoll density gradient (layers of $21,26,43,40$, and $60 \%$ Percoll). The gradient was centrifuged at $800 \mathrm{~g}$ for $30 \mathrm{~min}$. The interface between 40 and $60 \%$ was collected and washed with medium to remove the Percoll. The presence of $3-\beta$ hydroxysteroid dehydrogenase activity was revealed by a histochemical technique described in details elsewhere (Bilinska et al. 1997). It was used to determine the purity of Leydig cells, which ranged from 90 to $95 \%$. Cells were resuspended in fresh culture medium supplemented with $2 \%$ fetal calf serum. They were plated in 12-well plates (150 000 cells/well). An aliquot of freshly isolated Leydig cells was also processed for RNA analysis.

\section{Cell line cultures}

The immortalized Leydig cell mLTC-1 line was kindly provided by DM Stocco (Texas Tech, Lubbock, TX, USA). The mLTC-1 cells were cultivated at $37^{\circ} \mathrm{C}$ in a humidified $5 \% \mathrm{CO}_{2}$ incubator. Culture medium was a RPMI 1640 medium (Sigma-Aldrich Corp.) supplemented with $10 \%$ fetal calf serum until cells reach sub-confluency (70\%), as described (Manna et al. 2004). Serum was then omitted, cells were rinsed abundantly, and fresh medium was replaced. 


\section{Cell treatment}

In the relevant experiments, $100 \mathrm{ng} / \mathrm{ml}$ hCG; (Organon, Puteaux, France) or $1 \mathrm{mM} \mathrm{bu}_{2} \mathrm{CAMP}$ (Sigma) diluted in culture medium were added to the cultures. For the $\mathrm{mLTC}-1$ cells, stimulation was performed 24, 6, and $2 \mathrm{~h}$ before cultures were terminated, whereas primary Leydig cells were stimulated $24 \mathrm{~h}$ after plating for 2,6 , and $24 \mathrm{~h}$.

\section{RNA extraction, RT-PCR, and semi-quantitative RT-PCR}

Procedure for RNA extraction and RT-PCR has been described elsewhere (Longin et al. 2001, Guyot et al. 2003). Briefly, specific primers were designed using the Gene Jockey sequence processor (Biosoft, Cambridge, Cambs, UK) and primer3 software, and the optimal temperature of annealing was defined for each couple of primers (Table 1). Negative controls contained water instead of cDNA. PCR with no RT reactions gave no product, eliminating the possibility of a genomic DNA contamination in the RNA preparations. Amplified cDNAs were visualized in a $1.5 \%$ agarose gel stained with ethidium bromide. A DNA ladder (Promega) was loaded on each gel and Hprt1 (hypoxanthine-guanine phosphoribosyl transferase) was used to ensure equal loading. PCR products were sequenced by Biofidal (Lyon, France). PCR product sequences were found to match the published sequences (not shown). Conditions for reliable semi-quantitative RT-PCR were optimized for each series of primers in the presence of $\alpha$-33P dATP $(0.75 \mu \mathrm{Ci} ; 2500 \mathrm{Ci} / \mathrm{mmol}$; Amersham Pharmacia Biotech Europe $\mathrm{GmbH}$ ), as described elsewhere (Guyot et al. 2003, Odet et al. 2004). The PCR products were separated on $8 \%$ PAGE in $1 \times$ Tris-borate-EDTA buffer. Gels were transferred to filter paper, dried, and exposed to Kodak biomax MR1 films (Sigma). The band densities were determined by scanning densitometric analysis (Scion image beta 4.03; Scion Corporation at www.scioncorp.com). Densitometry data were normalized using Hprt1.

\section{Quantitative PCR}

Real-time PCR was carried out using the LightCycler DNA Master SYBR Green I kit (Roche Diagnostics $\mathrm{GmbH}$ ) in a LightCycler Instrument (Roche Diagnostics GmbH). The PCR was performed with $0.4 \mu \mathrm{M}$ of each primer, between 3 and $5 \mathrm{nM}$ $\mathrm{MgCl}_{2}, 1.5 \mu \mathrm{l}$ LightCycler DNA Master SYBR Green I in a total volume of $20 \mu \mathrm{l}$. After the initial denaturation step of $8 \mathrm{~min}$ at $95{ }^{\circ} \mathrm{C}$, the reaction conditions were 45 cycles of $95{ }^{\circ} \mathrm{C}$ for $15 \mathrm{~s}$, 60 or $64{ }^{\circ} \mathrm{C}$ (depending on the primer; Table 1 ) for $5 \mathrm{~s}$, and $72{ }^{\circ} \mathrm{C}$ for 8-16 s. The fluorescence intensity of SYBR Green was read on the LightCycler after the end of each extension step. Melting curve analyses were performed immediately following the final PCR cycle to verify the specificity of the PCR product by looking at its Tm. Rp/19 gene was chosen as the reference for normalizing target gene. It was consistently and reproducibly expressed in all samples, and it did not vary following hCG treatment (data not shown). Relative quantification was made by the standard curve method for both target and housekeeping gene (endogenous control) in each sample. A series of dilutions of calibrator sample (external standard) was included in each experiment in order to generate an external standard curve. Then the concentration of the target in each sample was divided by the concentration of the housekeeping gene in each sample, thereby normalizing the samples. Relative quantification was carried out using the LightCycler Relative Quantification Software (version 1.0). The calculation of data was based on the crossing point values obtained by the LightCycler Software (Roche Diagnostics $\mathrm{GmbH}$ ). To correct for sample heterogeneity and variability of detection, the results were calculated as the target/reference ratio of the sample divided by the target/ reference ratio of the calibrator.

\section{Statistical analysis}

All experiments made on duplicates or triplicates have been performed at least thrice with independent preparations of cells. All values are the mean \pm s.E.M. of 3-7 points, as precised in the text or in the figures. The significance of the results of semi-quantitative PCR data was examined by Kruskal-Wallis one-way ANOVA on ranks (comparison between several groups) followed by Dunn's test (multiple comparisons versus control group). The significance of the results of quantitative PCR data was examined by $t$-test. $P<0.05$ was considered significant. All statistical analyses were done with the aid of the Sigmastat 3.1 software package (Systat Software Inc., Point Richmond, CA, USA).

\section{Acknowledgements}

We are indebted to Douglas $M$ Stocco (Texas University, Lubbock, TX, USA) for providing us with the mLTC-1 cells. We are grateful to Catherine Rey (Profilexpert, Lyon) for carrying out real-time PCR experiments. This work was supported by Inserm U418 (Institut National de la Santé et de la Recherche Médicale), INRA UMR 1245 (Institut National de la Recherche Agronomique), and by the University of Lyon Claude Bernard (UCBL1). Adélie Vérot was funded by Organon (Azko, Nobel). Fanny Odet was funded by MRT (Ministère de la Recherche et de la Technologie) and FRM (Fondation pour la Recherche Médicale).

S Mazaud Guittot, A Vérot, F Odet, M A Chauvin and B le Magueresse-Battistoni have no conflict of interest to declare.

\section{References}

Aumailley M, Bruckner-Tuderman L, Carter WG, Deutzmann R, Edgar D, Ekblom P, Engel J, Engvall E, Hohenester E, Jones JC et al. 2005 A simplified laminin nomenclature. Matrix Biology 24 326-332.

Bilinska B, Genissel C \& Carreau S 1997 Paracrine effect of seminiferous tubule factors on rat leydig cell testosterone production: role of cytoskeleton. Biology of the Cell 89 435-442.

Carreau S, Papadopoulos V \& Drosdowsky MA 1988 Stimulation of adult rat Leydig cell aromatase activity by a Sertoli cell factor. Endocrinology 122 1103-1109.

Clark AM, Garland KK \& Russell LD 2000 Desert hedgehog (Dhh) gene is required in the mouse testis for formation of adult-type Leydig cells and normal development of peritubular cells and seminiferous tubules. Biology of Reproduction 63 1825-1838.

Colognato H \& Yurchenko PD 2000 Form and function: the laminin family of heterotrimers. Developmental Dynamics 218 213-234.

Dano K, Behrendt N, Hoyer-Hansen G, Johnsen M, Lund LR, Ploug M \& Romer J 2005 Plasminogen activation and cancer. Thrombosis and Haemostasis 93 676-681. 
Denolet E, De Gendt K, Allemeersch J, Engelen K, Marchal K, Van Hummelen P, Tan KAL, Sharpe RM, Saunders PTK, Swinnen JV, et al. 2006 The effect of a Sertoli cell-selective knockout of the androgen receptor on testicular gene expression in prepubertal mice. Molecular Endocrinology 20 321-334.

Diaz ES, Pellizzari E, Meroni S, Cigorraga S, Lustig L \& Denduchis B 2002 Effect of extracellular matrix proteins on in vitro testosterone production by rat Leydig cells. Molecular Reproduction and Development 61 493-503.

Diaz ES, Pellizzari E, Casanova M, Cigorraga SB \& Denduchis B 2005 Type IV collagen induces down-regulation of steroidogenic response to gonadotropins in adult rat Leydig cells involving mitogen-activated protein kinase. Molecular Reproduction and Development 72 208-215.

Dym M 1994 Basement membrane regulation of Sertoli cells. Endocrine Reviews 15 102-115.

Enders GC, Kahsai TZ, Lian G, Funabiki K, Killen PD \& Hudson BG 1995 Developmental changes in seminiferous tubule extracellular matrix components of the mouse testis: alpha 3(IV) collagen chain expressed at the initiation of spermatogenesis. Biology of Reproduction 53 1489-1499.

Fawcett DW, Neaves WB \& Flores MN 1973 Comparative observations on intertubular lymphatics and the organization of the interstitial tissue of the mammalian testis. Biology of Reproduction 9 500-532.

Gersdoff N, Kohfeldt E, Sasaki T, Timpl R \& Miosge N 2005 Laminin gamma3 chain binds to nidogen and is located in murine basement membranes. Journal of Biological Chemistry 280 22146-22153.

Griswold MD 1998 The central role of Sertoli cells in the seminiferous epithelium. Seminars in Cell and Developmental Biology 9 411-416.

Guyot R, Magre S, Leduque P \& Le Magueresse-Battistoni B 2003 Differential expression of tissue inhibitor of metalloproteinases type 1 (TIMP-1) during mouse gonad development. Developmental Dynamics 227 357-366.

Häger M, Gawlik K, Nyström A, Sasaki T \& Durbeej M 2005 Laminin $\alpha 1$ chain corrects male infertility caused by absence of laminin $\alpha 2$ chain. American Journal of Pathology 167 823-833.

Hudson BG, Tryggvason K, Sundaramoorthy M \& Neilson EG 2003 Alport's syndrome, Goopasture's syndrome and type IV collagen. New England Journal of Medicine 348 2543-2556.

livanainen A, Morita T \& Tryggvason K 1999 Molecular cloning and tissuespecific expression of a novel murine laminin gamma3 chain. Journal of Biological Chemistry 274 14107-14111.

Kahsai TZ, Enders GC, Gunwar S, Brunmark C, Wieslander J, Kalluri R, Zhou J, Noelken ME \& Hudson BG 1997 Seminiferous tubule basement membrane. Journal of Biological Chemistry 272 17023-17032.

Koch M, Olson PF, Albus A, Jin W, Hunter DD, Brunken WJ, Burgeson RE \& Champliaud MF 1999 Characterization and expression of the laminin gamma3 chain: a novel, non-basement membrane-associated, laminin chain. Journal of Cell Biology 145 605-618.

de Kretser DM, Kerr JB \& Paulsen CA 1975 The peritubular tissue in the normal and pathological human testis. An ultrastructural study. Biology of Reproduction 12 317-324.

Kuopio T \& Pelliniemi LJ 1989 Patchy basement membrane of rat Leydig cells shown by ultrastructural immunolabeling. Cell and Tissue Research 256 45-51.

Liu L \& Smith JW 2000 Identification of ADAM31: a protein expressed in Leydig cells and specialized epithelia. Endocrinology 141 2033-2042.

Longin J, Guillaumot P, Chauvin MA, Morera AM \& Le MagueresseBattistoni B 2001 MT1-MMP in rat testicular development and the control of Sertoli cell proMMP-2 activation. Journal of Cell Science $\mathbf{1 1 4}$ 2125-2134.

Le Magueresse-Battistoni B 2007 Serine proteases and serine protease inhibitors in testicular physiology: the plasminogen activation system. Reproduction 134 721-729.

Le Magueresse-Battistoni B, Pernod G, Sigillo F, Kolodie L \& Benahmed M 1998 Plasminogen activator inhibitor-1 is expressed in cultured rat Sertoli cells. Biology of Reproduction 59 591-598.

Manna PR, Huhtaniemi IT \& Stocco DM 2004 Detection of hCG responsive expression of the steroidogenic acute regulatory protein in mouse Leydig cells. Biological Procedures Online 6 89-93.

Mathur PP, Grima J, Mo MY, Zhu LJ, Aravindan GR, Calcagno K, O'Bryan M, Chung S, Mruk D, Lee WM, et al. 1997 Differential expression of multiple cathepsin mRNAs in the rat testis during maturation and following lonidamine induced tissue restructuring. Biochemistry and Molecular Biology International 42 217-233.

Odet F, Guyot R, Leduque P \& Le Magueresse-Battistoni B 2004 Evidence for similar expression of protein $\mathrm{C}$ inhibitor and the urokinase-type plasminogen activator system during mouse testis development. Endocrinology 145 1481-1489.

Odet F, Vérot A \& Le Magueresse-Battistoni B 2006 The mouse testis is the source of various serine proteases and SERine Protease Inhibitors (SERPINs). Serine proteases and SERPINs identified in Leydig cells are under gonadotropin regulation. Endocrinology 147 4374-4383.

Page-McCaw A, Ewald AJ \& Werb Z 2007 Matrix metalloproteinases and the regulation of tissue remodelling. Nature Reviews. Molecular Cell Biology 8 221-233.

Penttilä TL, Hakovirta H, Mali P, Wright WW \& Parvinen M 1995 Folliclestimulating hormone regulates the expression of cyclic protein-2/cathepsin $\mathrm{L}$ messenger ribonucleic acid in rat Sertoli cells in a stage-specific manner. Molecular and Cellular Endocrinology 113 175-181.

Petrusz P, Jeyaraj AD \& Grossman G 2005 Microarray analysis of androgenregulated gene expression in testis: the use of the androgen-binding protein (ABP)-transgenic mouse as a model. Reproductive Biology and Endocrinology 3 70-77.

Pöschl E, Schöltzer-Schrehardt U, Brachvogel B, Saito K, Ninomiya Y \& Mayer U 2004 Collagen IV is essential for basement membrane stability but dispensable for its assembly during early development. Development 131 1619-1628.

Primakoff P \& Myles DG 2000 The ADAM gene family: surface proteins with adhesion and protease activity. Trends in Genetics 16 83-87.

Siu MK \& Cheng CY 2004 Dynamic cross-talk between cells and the extracellular matrix in the testis. BioEssays 26 978-992.

Stocco DM, Wang X, Jo Y \& Manna PR 2005 Multiple signaling pathways regulating steroidogenesis and steroidogenic acute regulatory protein expression more complicated than we thought. Molecular Endocrinology $192647-2659$.

Timpl R 1996 Macromolecular organization of basement membranes. Current Opinion in Cell Biology 8 618-624.

Timpl R \& Brown J 1996 Supramolecular assembly of basement membranes. BioEssays 18 123-132.

Ulisse S, Rucci N, Piersanti D, Carosa E, Graziano FM, Pavan A, Ceddia P, Arizzi M, Muzi P, Cironi L, et al. 1998 Regulation by thyroid hormone of the expression of basement membrane components in rat prepubertal Sertoli cells. Endocrinology 139 741-747.

Vernon RB, Lane TF, Angello JC \& Sage H 1991 Adhesion, shape, proliferation, and gene expression of mouse Leydig cells are influenced by extracellular matrix in vitro. Biology of Reproduction 44 157-170.

Wang RS, Yeh S, Chen LM, Lin HY, Zhang C, Ni J, Wu CC, di Sant'agnesse PA, de Mesy-Bentley KL, Tzeng CR, et al. 2006 Androgen receptor in Sertoli cell is essential for germ cell nursery and junctional complex formation in mouse testes. Endocrinology 147 5624-5633.

Yan HH \& Cheng CY 2006 Laminin alpha3 forms a complex with beta3 and gamma3 chains that serves as the ligand for alpha6beta1-integrin at the apical ectoplasmic specialization in adult rat testes. Journal of Biological Chemistry 281 17286-17303.

Yashwanth R, Rama S, Anbalagan M \& Rao AJ 2006 Role of estrogen in regulation of cellular differentiation: a study using human placental and rat Leydig cells. Molecular and Cellular Endocrinology 246 114-120.

Zhang C, Yeh S, Chen YT, Wu CC, Chuang KH, Lin HY, Wang RS, Chang YJ, Mendis-Handagama C, Hu L, et al. 2006 Oligospermia with normal fertility in male mice lacking the androgen receptor in testis peritubular myoid cells. PNAS 103 17718-17723.

Zheng P, Kerry J, Harvey SJ, Sado Y, Ninomiya Y, Jefferson B, Jacobs R, Hudson BG \& Thorner PS 2005 Regulation of collagen type IV genes is organ-specific: evidence from a canine model of Alport syndrome. Kidney International 68 2121-2130.

Received 15 December 2007

First decision 21 January 2008

Accepted 21 January 2008 